\title{
Analysis of Buying and Selling Through Online Transactions Perspective of Islamic Law
}

\author{
Ahmad Faruk, Moh Mahmud \\ Institut Agama Islam DarusslamBlokagung \\ $\underline{\text { Ahmadfaruk028@gmail.com, Mohmahmud060578@gmail.com }}$
}

\begin{abstract}
Abstrak
Research entitled Analysis of Sale and Purchase Through Online Transactions Using the As Salam Agreement Viewed From Islamic Law (Case Study of Buying and Selling Through Online Transactions Using the AsSalam Agreement) This research is normative legal research or library law research which is prescriptive and the method of approach uses qualitative methods. Research on Islamic law through Islamic law research, research on the sale and purchase of AsSalam through online transactions conducted by students of IAI Darussalam Blokagung Banyuwangi Regency. This article is a type of qualitative research that uses descriptive analysis, which describes research data collected both from interviews, observations and research while being collected at the IAIDA Blokagung campus in Banyuwangi Regency. The results showed that basically all forms of muamalah are permissible or permissible, except as otherwise determined by the Al-Quran Sunnah and Ijma'. Buying and selling which is included in the field of muamalah and is specialized in this writing namely as-salam in terms of Islamic law is permissible or halal done with various mechanisms that exist as long as it does not conflict with the Al-Quran As-Sunnah and Ijma'. Then online transactions that are used as a medium or in this case the internet in buying and selling assalam if viewed from Islamic law is permissible as long as its use is not contrary to Islamic principles. Islamic law originating from the Islamic religion itself, views online media as permissible, not in conflict with Islamic principles. Regarding the operational use of the internet in this case, published by buying and selling greetings, further to Urf'. This is what convinces researchers that Islamic law with its three sources has provided a complete and flexible explanation of things that are updated nowadays or modern.
\end{abstract}

\section{Keywords: Online Transactions, Islamic Law}

\section{A. INTRODUCTION}

The Qur'an and Sunnah of the Apostles cover a great deal of all lines of life and are always ideal for the past, present, and future. Human relations with God are governed in the field of worship and human relations with each other are regulated in the field of Muamalah in the broad sense, both individual and general. In social life consciously or not humans always relate to one another to meet their needs. In Islam, the association of life where everyone does an action in relation to others is called Muamalah. In this association of life, each person has an interest in other people who are nothing but Muamalah activities, and in essence Muamalah is not only 
consumptive and only contains material elements to gain benefits in the world, but also the benefits of certain rights in the afterlife by taking into account the principles of Muamalah which allowed according to Islam (Buchari Alma. 2003: 21).

Islam places Muamalah so important, because its actions give rise to rights and obligations which form the largest part of human life. The law of Muamalah talks about objects, and the kinds of things, human relations with objects concerning property rights, revocation of property rights of certain associations, such as buying and selling, debt and debt, leases and so on. Even though the field of Muamalah concerns worldly life relationships, religious values cannot be separated. Religious values in the field of Muamalah are reflected by the existence of Halal and Haram laws which must always be considered (Erieka Censerianto. 2011: 4-5).

\section{B. LITERATURE REVIEW}

Muamalah is a means of exchanging goods or something that provides benefits in a specified manner. Economic activity in the view of Islam is buying and selling which is included in the field of muamalah, which of course has its own law. Buying and selling in Islam can be said by an exchange of goods with other goods in a certain way (contract). In general, buying and selling in Islam explains the existence of a physical transaction, by presenting the object during the transaction, or without presenting the ordered object. , but with provisions must be stated concretely nature, whether submitted directly or submitted later until a certain time limit, such as the assalam transaction and al-istishna transaction. In the current era of globalization, many emerging models of buying and selling using the sophistication of modern technology. This is marked by the development of electronic media that affect aspects of human life, especially in buying and selling transactions through online media (internet) (Friska Muthi Wulandari: 2015: 2)

The system of buying and selling using online (internet) according to the view of Islamic law is a system of buying and selling using a contract as salam (message). The role of the internet today is not only to communicate, but also as a tool for information retrieval. Communication tools such as computers, laptops, smartphones make it very easy for people to connect to the internet to make buying and selling transactions (Runto Hediana and Ahmad Dasuki Aly: 2013: 47).

According to scholars Syafiiyah and Hanabilah the contract as salam is a system of selling and buying in cash or in a hurry but the delivery of goods is suspended by the practice where the goods being traded do not yet exist when the transaction is made, and the buyer makes payment in advance while the delivery of new goods is done at a later date (M. Iqbal A 2014: 6).

\section{RESEARCH METHODS}




\section{Type of Research}

This type of research is carried out by field research, namely researchers that are directly related to the object under study or a natural phenomenon. According to Sugiyono (2012: 35) using this type of research aims to describe or describe the situation in the field systematically with the facts and the proper interpretation and interconnected data.

This research examines the mechanism used in the online buying and selling process by using the as salam agreement, by collecting data obtained from informants in the scope of students of the Darussalam Darussalam Institute of Religion, Banyuwangi Regency.

2. Research Subjects and Objects

a. Research subject

The research subject is something that is examined both people, objects, or institutions (organizations) and which will basically be subject to conclusions from the results of the study (Afdhol Hanaf, 2012: 03). In this study the subjects who became the informants were students of the Darussalam Islamic Institute Blokagung Banyuwangi Regency.

Reasons for selecting informants:

1) Experienced in buying and selling online

2) Frequent ordering through online buying and selling transactions

3) Having more value in the field of religious knowledge because it is under the auspices of the boarding school

b. Research object

The object of research is the nature of the state of an object, person, or being the center of attention and research objectives (Afdhol Hanaf, 2012: 04). The object of this study is the Darussalam Islamic Institute of Blokagung Banyuwangi Regency.

Reasons for selecting the research object:

1) Under the auspices of the boarding school foundation

2) Having the most students among universities under the auspices of the Ministry of Religion in Banyuwangi Regency

3) The development of buying and selling through the internet within universities is very rapid

\section{Data Sources}

There are two kinds of data sources that researchers use, namely primary data sources and secondary data sources:

a. Primary Data Sources

Primary data sources are data that are directly obtained from the first data source at the research location or research object (M. Burhan Bungin, 2004: 30). Data obtained from informants namely students who make online purchases. This study only discusses data and information obtained based on existing realities or based on results from the field. 


\section{Terakreditasi Nasional Sinta 4: SK. No.30/E/KPT/2019}

\section{b. Secondary Data Sources}

Secondary data sources are data obtained from second sources or secondary sources and the data we need. In this research the secondary data is in the form of documents. The data collection method is called the documentation method, where this method is used to obtain data in the form of written data such as books, magazines, newspapers, papers, research reports.

c. Method of collecting data

One important stage in the research process is the data collection stage. This is because data is the most important factor in a study, without the data collected it is not possible for a study to succeed. In this study the data collection methods the researchers used were by:

1) Observation

Observation is a direct observation of decision makers and their physical environment and / or direct observation of an ongoing activity. Where researchers entered the office of the Institute of Islamic Religion of Darussalam by directly looking at online trading activities carried out by IAIDABlokagung students in Banyuwangi Regency.

2) Interview or Interview

Interview or interview is a question and answer process in research that takes place orally where two or more people face to face listen directly to information related to the researcher (Kholid, 2009: 3). The interview method used by the compiler is in-depth interviews is the process of obtaining information for research purposes by way of question and answer while face to face between the interviewer and the informant or the person being interviewed (Juliansyah Noor, 2014: 138). In this case the research subjects were students of IAI Darussalam Banyuwagi.

3) Documentation

Documentation is a data collection technique used to collect data in the form of written data sources that contain information and explanations as well as thoughts about phenomena that are still actual and in accordance with research problems (Muhammad, 2008: 4). Documentation is a data collection technique used to collect data in the form of written data sources that contain information and explanations as well as thoughts about phenomena that are still actual and in accordance with research problems (Muhammad, cited in Musyafi Ulya, 2016). In detail, documentary materials are divided into several types, namely autobigraphy, personal letters, books or diaries, memorials, clippings, government or swast documents, server and flash disk data, and data stored on a web site (Juliansyah Noor, 2014: 141).

\section{Data Analysis Method}


According to Bogdan (quoted by Sugiyono, 2013: 244) Data analysis is the process of systematically searching and compiling data obtained from interviews, field notes, and documentation by organizing data into categories, describing it into units, synthesizing, arrange into patterns, choose what is important and what will be learned, and make conclusions so that it is easy to understand and the theme can be shared with others (Sugiyono, 2015: 244).

This data analysis technique using an interactive model is the simplest data analysis technique and is widely used by qualitative researchers, namely the data reduction stage, the data presentation stage or data analysis after data collection, the conclusion and verification stage. The analysis consists of three lines of activities that occur simultaneously including data reduction, presentation of data drawing conclusions / verification (Matthew B. Miles and A. Michael Huberman, 2014: 16). Data analysis technique is the most decisive step of a study, because data analysis serves to infer the results of research

\section{RESULT AND DISCUSSION}

Salam is the language of origin of the population of Hijaz while salaf is a language that originates from the population of Iraq, according to the meaning of syara 'is called salam because it surrenders payment (ra's al-maal) in the majlis and is called salaf because payments are made at the beginning.

In terminology, a salam contract can be defined as the sale and purchase of goods (muslam fih) something that is characterized in dependents (dzimmah) using the language of salutation or salaf agreement if not using lafadz salam or salaf, then it is included in the category of ordinary sale and purchase contract (Ibrahim Al Bajury, 2007: 679).

Sale and purchase greetings are selling goods that are not present and cannot be seen when the contract so that it is still mentioned only the characteristics and the responsibility of the seller to bring it (Andi Ali Akbar, 2014: 35)

Syafi'iyyah and Hanbali scholars define by: "the contract is agreed upon by determining certain characteristics by paying the price first, while the goods are then delivered later in a contract agreement" (Eriek Censerianto, 2011: 25).

What is meant by the term safih is a person who is prohibited from practicing tasarruf because it is feared that he will do it in vain or so forth. Ie, because it's still small or has a crazy illness. For example, because his speech is difficult or he does not know what he should do and what he should not do (do not know what is right and wrong). This verse orders witnessing next to the text to further strengthen trust. This applies only in matters of property and everything related to it. In fact a woman's testimony is required by two people to occupy the place of a man, only because the woman's reasoning is lacking. This verse contains meaning which indicates fair conditions for witnesses. The meaning of this verse is muqayyad (binding) which is used as a legal grip by Imam Shafi'i in dealing with all the absolutes in the Qur'an 
concerning the command to hold unconditional witnessing. This verse is used as a proposition by those who reject the testimony of someone unknown. For this reason, he requires that a witness must be fair again to be approved. Namely if one of the two women forgot about his testimony, that is to say, the person who forgets will be reminded by his friend of the testimony he has stated. Based on this understanding there are a number of scholars who read fatuzakkira using tasydid (Tafsir Ibn Kathir, 2017).

Whereas someone who believes that a woman's testimony is accompanied by another woman, making her testimony the same as the testimony of a man; actually this opinion is far from the truth. The right opinion is the first. The meaning of this verse is according to an opinion that 'if the witnesses are called to give their testimony, then they must bring it up'. According to another opinion, this meaning is the opinion of jumhur ulama; and what is meant by his word: And do not witnesses are reluctant (give information) when called (Al-Baqarah: 282), shows the meaning of giving information essentially. While his words, "Ash-shuhada" is meant by those who bear the testimony. For this reason, if he is called to provide information, he must fulfill it if it has been determined. But if it is not determined, then the law is fard kifayah. This is the perfection of the instructions, namely the order to record rights, both small and large. Because it was mentioned at the beginning. He is your bag, meaning that you don't feel reluctant to record any amount of rights, whether small or large, until the deadline for payment. That is, the thing that we instruct you to record is the right when transactions are not made in cash is a fairer thing in the sight of God. It also strengthened the testimony, that is, the witness's testimony was stronger when he signed his name; because when he sees it, he will certainly remember his testimony (Tafsir Ibn Kathir, 2017).

Considering it was possible that if he did not sign his name, he forgot his testimony, as was the case. That is, more erasing doubt; even if you disagree, then the notes that you have written between you can be used as a reference, so that disputes between you can be resolved and doubts disappear. In other words, if a sale and purchase transaction is made in cash and the handover of goods and payment, never mind if no writing is done, remember there is no prohibition if you do not use it, namely make a testimony to your rights if you use the tempo of time, or do not use the tempo of time. In other words, make a witness of your rights under any circumstances. let the writer and witness not deviate, for example he writes things that are different from what is suggested to him, while the witness gives information that is different from what he heard, or he hides his testimony as a whole. Namely if you deviate from what was ordered to you or you do what you are forbidden to do, then this is an act of wickedness that you do (Tafsir Ibn Kathir, 2017).

1. The Hadith of the Prophet Muhammad 
Ibn Abas related that the Prophet came to Madina where the inhabitants performed salaf in fruits for a period of one, two, and three years. He said:

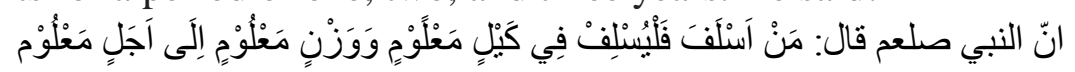

It means: "Whoever performs the salaf, should carry it out with clear measurements and clear scales too, up to a certain time limit" (HR. At-Turmudzi).

Fatwa of the National Sharia Council of the Indonesian Ulema Council (DSNMUI) has become one of the references regarding Salam, as stated in: "The provisions regarding payment, namely: (1) the means of payment must be known the amount and form, whether in the form of money, goods, or benefits; (2) payment must be made when the contract is agreed; (3) payments may not be in debt relief (Eriek Censerianto, 2011: 26-27).

1) Pillars and As-Salam Terms

There are five pillars of salutation (Muhammad bin Ahmad bin Umar As Syathiry, 2011: 365) namely:

a) People who place orders (Muslim)

b) People who receive orders (muslam ilaih)

c) Ordered items (muslam fih)

d) Upfront costs (ra's al-mal)

e) Ijab qabul (shigat).

2) According to Muhammad Syafi'i Antonio, 2001: 109 in his book there are several pillars and conditions used in the as salam transaction, including: The implementation of the greetings must meet the following pillars:
a) Muslim (buyer)
b) Musila ilaih (seller)
c) Capital or money
d) Muslam fiih (goods)
e) Shighat (greeting)

\section{Best regards}

1) Capital transaction as regards

The requirements that must be fulfilled in the capital as regards are as follows:

2) Capital must be known

The goods supplied must be of the type, quality and quantity. The initial law regarding payment is that it must be in cash.

3) Recipients of assalam payments

Most scholars' require that greetings be paid at the contract. This is so that payments made by buyers are not used as seller debt. More specifically, greeting payments cannot be in the form of discussion of debt to be paid from the seller. This is to prevent the practice of usury.

a) Al-Muslam Fiih (goods) 
Among the conditions that must be fulfilled in the fiq muslam or goods that are traded in bai 'as salam are as (Team Laskar Pelangi, 2013 :).

a. Must be specific and can be recognized as debt

b. Must be clearly identified to reduce errors

c. Delivery of goods is done in the future

d. May determine the date of time in the future for delivery of goods

e. Contracting parties must indicate the agreed place where the goods must be delivered

f. The ulama 'forbade the replacement of fiqa muslam with other goods. The exchange or replacement of this greeting item is not permitted, because even though it has not been handed over, the item no longer belongs to the ilaih muslam but has become the property of the Muslim or the buyer.

b) According to (Andi Ali Akbar, 2014: 35) in his book, there are harmony and conditions in buying and selling greetings, namely as follows:

(a) 'aqidaini: i.e. seller (Muslam ilaih) and buyer (Muslim). Both conditions are the same as the sale and purchase agreement.

(b) Ma'qud 'alaihima; i.e., ordered items (muslam fiih) and payment instruments (ra's al-maal)

Fiq muslam requirements:

(1) Mentioned all the characteristics and criteria in detail in accordance with what Muslims want.

(2) The shape of the goods must be in accordance with the order

(3) Nature and levels must be detected, not like:

(4) Goods made from several types of main ingredients, such as porridge of harisah (from flour and meat), ice juice, STMJ, and others.

(5) Not made by cooking, boiling, frying, diopen, roasting or baking

(6) rare items such as mangoes not in season.

(7) Not in the form of goods that are determined but must be in the form of debt or dependents, that is, goods must not be present and cannot be seen during the contract, even though the surrender can be agreed at that time.

Terms of payment (ra's al maal)

a. Must be cash, and given before the two parties separate from the contract.

b. Obviously, by the way seen before the eyes. If not in front of the eye then by explaining the price and what kind of goods will be used to pay

c. Sighat; deal transactions from both parties (ijab-qabul). The conditions are the same as in sighat bai '.

In addition to the above conditions, there are five more conditions that must be fulfilled in the greeting agreement.

(1) If the surrender of the Islamic holy mosque is affixed, it must be explained the time of maturity and place of surrender. 
(2) The general condition of fiih muslam already exists at the time of delivery, not as a rare item.

(3) The salam contract must be najizan there must be no conditions.

(4) The delivery of payment instruments (ra's al maal) must be essential before separating from the contract. If it is not legal, such as surrender uses khawalah contract.

The priests of the schools differ in regards to buying and selling greetings on items that can be counted, but the only things that can be excess and decrease the situation, such as pomegranates and watermelons, Hanafi priests are of the opinion that it is not permissible to carry out a salam agreement on the fruit both weighed as well as counted, while Imam Maliki thinks it is permissible absolutely, while our school of thought Imam Shafi'i believes it can be weighed, and from Imam Hambali obtained two narrations, the more famous is allowed to be counted absolutely (Muhammad bin 'Abdurrahman ad-Dimasyqi , 2004: 246).

Some opinions say the implementation of assalam in the sale and purchase of goods that are in the form of dependents with cash payments in the form of contract. In other terms, bai'us salam is a contract of ordering an item with agreed criteria and with cash payments at the time the contract is in progress. Thus, Akadas Salam has specific criteria when compared to other types of buying and selling, including (Shalih Ali Fauzan, 2017: 148):

(1) Payments are made up front (cash in place of the contract), therefore the sale and purchase is also called assalaf.

(2) Handover of goods is postponed until the time specified in the contract agreement.

Giving weight and objectivity in this study was taken through a systematic step, namely to inventory various writings and research on buying and selling online both in the form of ordinary writing and scientific work. Research review and record some previous research with some main topics that have relevance to the title to be examined. The following is an overview of previous research:

Erieka Censerianto (2011) "Buying and Selling As-Salam through Online Transactions Reviewed from Islamic Law" This study aims to determine the mechanism of buying and selling assalam through online transactions, then the next goal is to find out the Islamic view of online transactions as a medium in buying and selling assalam. This research is a normative legal research or prescriptive library law research, studying the legal concepts used in buying and selling assalam through online transactions in terms of Islamic law. The research approach in this research is the concept approach and analytical approach. Legal research sources used are primary legal materials and secondary legal materials. The legal material collection technique used is the study of documents or library materials both from print and electronic media. The legal material analysis technique used in this study is the method of deductive reasoning. The results of this study are that buying and selling transactions 
using an online or ordering model based on Islamic legal sources view that online media is permissible as long as its use is not in conflict with Islamic principles

Friska Muthi Wulandari (2015) Safe and Sharia Online Trading (Study of the Views of Online Businesses Among Students and Alumni of the Faculty of Sharia and Law of UIN Sunan Kalijaga). This type of research is field research. Data collection using structured interview methods. Data analysis was performed using the theory of buying and selling and buying and selling ethics, while data collection for samples was conducted using a purposive sampling method, namely respondents from online business people from students and alumni of the Faculty of Sharia and Law of UIN Sunan Kalijaga. The results of this study, the first transaction buying and selling online via transfer via ATM is safe if the receipt of the transfer receipt is photographed and then sent via BBM or other application to the seller, as well as proof of delivery addressed to the buyer. Second, secure transactions are carried out using the COD (Cash On Delivery) system, because buyers can see the desired goods directly to avoid any defects in goods, in addition to payment can also be done directly, while to minimize the risks that often occur in buying and selling online, online businesses can use a joint account (rekber) as a third party in online transactions.

Chacha Andira Sari (2015) "Online Shopping Behavior Among College Students of AstropolitanUniversities. The rise of consumption through online shops by students is one of the background problems in this research. Generally students do online shopping not based on needs alone, but for the sake of pleasure and lifestyle so as to cause a person to become wasteful or better known as consumptive behavior or behavior consumerism. This research is focused into two focuses, namely regarding the pattern of consumptive behavior of online shop shopping among Anthropology students of FISIP Airlangga University, and the problems faced by Anthropology students of FISIP Unair in shopping online shop. This study uses a qualitative research method involving 7 respondents within the scope of Anthropology FISIP Airlangga University. In this research, it is described that the consumptive behavior of shopping online among female students of Anthropology, Faculty of Social and Political Sciences, Airlangga University, is indicated by their unnatural spending intensity, which is on average once a month and costs starting from IDR 45,000, where cosmetics that can be obtained for example eyeliner, regular lipstick without glow and others. The problems that are often faced by female students when shopping online are mostly related to the product received that does not match the posted picture, length of delivery time, slow response from online shop in response consumer orders, and shipping costs are relatively expensive. Judging from the research above there are similarities and differences which are located below:

2. Equation

a. This research is a normative legal research or library research law that is prescriptive in nature, studying the legal concept of buying and selling online using an assalam agreement. 
b. The main topics of analysis are the same trading methods through online transactions

c. Online buying and selling mechanism using Islamic law (akad as salam)

3. Difference

a. The research subjects used in this study were students of IAI Darussalam Blokagung Banyuwangi Regency

b. The title used in this study is not the same as the previous research title

c. Researchers examine the perception of the mechanism of buying and selling using the online system through a contract as salam.

\section{Use Of Research Results}

The value of a study is determined by the amount of uses that can be taken from the study. Research is expected to have theoretical and practical uses. The intended use of the author of theoretical and practical uses is:

1. The use of theoritis in this study to increase knowledge related to the law of sale and purchase through online transactions through sharia by using the contract as regards

2. The practical uses of this research are:

a. For Research Objects

The usefulness of research for the object of research is to contribute knowledge in the field of sharia law to the students and students.

b. For the Darussalam Islamic Institute Blokagung Banyuwangi Regency

3. The usefulness of research for the Darussalam Islamic Institute of Blokagung Banyuwangi Regency is to make a contribution of knowledge to consumers buying and selling online in general and to IAIDA students and Darussalam Blokagung boarding school students in particular about the sale and purchase of greetings through online transactions conducted by IAIDA students and students Darussalam Blokagung boarding school, and in order to be more organized in carrying out the process of buying and selling transactions online in sharia.

\section{E. CONCLUTION}

From the explanation above, it can be concluded that the sale and purchase through online transactions using the greeting agreement made by students of IAI Darussalam Blokagung, Banyuwangi Regency are as follows:

1. The online transaction intended by the researcher here is a medium or modern facility which is often referred to as the internet and is not yet known and was used in the time of the Prophet SAW. Buying and selling through online transactions which in this case researchers specialize in internet media is actually a real example of buying and selling greetings. So without realizing it, buying and selling or online trading which is often called e-commerce already uses the greeting system in practice. Buying and selling through online transactions using 
the agreement as salam in the mechanism involves the internet media as a liaison between the parties and uses the bank for the payment process.

2. Islamic law originating from the religion of Islam itself, looking at online media is permissible as long as its use is not contrary to Islamic principles. Regarding operational use of the internet in this case the relationship with selling belionline using regards, more returned to urf '. This is what convinces the author that Islamic law with its three sources has provided a complete and flexible explanation of things that smell contemporary or modern.

\section{REFERENCES}

Al Baijury, Ibrahim. (2007).Al Baijury. Surabaya. Darul Ihya'.

Al Masyhur, Abi Bakar. (2007). Ianatuttholibin.

Al Quran Karim Terjemah Depag 2006

Andi Ali Akbar. (2014). Fiqh Muammalah. Blokagung Banyuwangi. Tb Darussalam. Bujairomi al khotib. (2007). Bujairomi Ala Al Khotib. Lebanon

Censerianto, Eriek. (2011). Jual Beli As Salam Melalui Trnsaksi Online di Tinju Dari Hukum Islam. (1): 1-5.

Chacha Andira Sari. (2015). Perilaku Berbelanja Online Di Kalangan Mahasiswi Antropologi Universitas Airlangga.

Hasan bin Ahmad bin Muhammad Al-Kaf. (2013). At-Taqrirotussadidah. Pasuruan Jawa Timur. Hadromi.

http://myQuran.com/Servodaeman/HukumElectronicCommerce.html>(22 juli 2017. Pukul 23:41).

http://www.iaida.ac.id/statuta-2/(16 Juli 2017. Pukul 22:35).

http://www.google.co.id/search?biw=320\&bih=460\&ei=iF1 WcfmIcXavgTOxqegDg

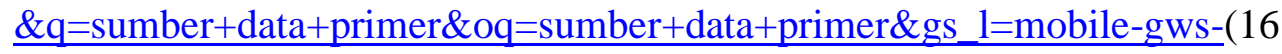
Juli 2017. Pukul 23:14).

http://rumahislam.com/sunan-abu-dawud/559-tafsir-depag-ri--qs-002-albaqarah-280.html (18 September 2017 pukul 8:30).

lama (http://pengusahamuslim.com/IbnuMunzir/fatwa dan nasehat agama/ jual beli as salam.html>(21 juli 2017. Pukul 20.45).

Miles, Matthew B. Dan A. Michael Huberman. Analisis Data Kualitatif (Penerjemah:Tjejep Rohendi Rohidi). Jakarta:Universitas Indonesia (UI-Press).

Mubarok, Abu Hazim, (2013). Fiqh Idola Terjemah Fathul Qorib. Jawa Barat: Mu'jizat. 
Muhammad bin 'Abdurrahman Ad-Dimasyqi. (2004). Fiqh Empat Mazdhab. Bandung. Hasyimi.

Noor Juliansyah. (2014). Metodologi Penelitian Skripsi, Tesis, Disertasi, dn Karya Ilmiah. Jakarta: Kencana.

Sugiyono. (2015). Metode Penelitian Kuantitatif, Kualitatif, dan R\&D. Jakarta : Alfabeta

Syafi'i Antonio, Muhammad. (2001). Bank Syariah Dari Teori ke Praktik. Jakarta. Gema Insan.

Tim Laskar Pelangi. (2013). Fiqh Muammalah. Kediri

Tim Penyusun Pedoman Penulisan Skripsi Fakultas Ekonomi dan Bisnis Islam. (2017). Pedoman Penulisan Skripsi. Banywangi : IAIDA.

Wasik, Akhmad. (2015). Analisis Hukum Islam Terhadap Murabahah Dalam Produk Cash Colleteral Financing di PT. Bank BNI Syariah Kantor Jember. Skripsi tidak diterbitkan. Banyuwangi: Ekonomi dan Bisnis Islam IAIDA Banyuwangi.

Wulandari, Friska Muthi. (2015). Jual Beli Online Yang Aman dan Syar'i. (2) 15-16.

Wawancara dengan Saudara Ahmad Fadil MarzuqiMahasiswa IAI Darussalam Blokagung Kabupaten Banyuwangi 22 Juli 2017.

Wawancara dengan Saudara M. Alfin Mubarok Mahasiswa IAI Darussalam Blokagung Kabupaten Banyuwangi Juli 2017.

Wawancara dengan Saudara Fatkhurrofiq Mahasiswa IAI Darussalam Blokagung Kabupaten Banyuwangi Juli 2017.

Wawancara dengan Saudara M. Rizal TaufiqMahasiswa IAI Darussalam Blokagung Kabupaten Banyuwangi Juli 2017.

Wawancara dengan Saudara Zulfanul Kirom Mahasiswa IAI Darussalam Blokagung Kabupaten Banyuwangi Juli 2017.

Wawancara dengan Saudara Mukhtar SyafaatMahasiswa IAI Darussalam Blokagung Kabupaten Banyuwangi Juli 2017 